\title{
Performance of the root system of tomato plants inoculated with arbuscular mycorrhizal fungi and submitted to the grafting technique
}

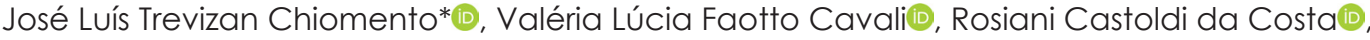

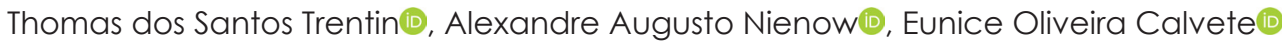

University of Passo Fundo, Passo Fundo, Brazil

${ }^{*}$ Corresponding author, e-mail: : jose-trevizan@hotmail.com

\begin{abstract}
Information about the combined use of arbuscular mycorrhizal fungi (AMF) in grafted horticultural crops are scarce, as is the case of tomato. Therefore, we investigated if the association between AMF and the grafting technique modifies the performance of the root system of tomato plants grown on substrate. The treatments, outlined in a two-factorial scheme, were absence of inoculation and two inoculants of AMF (Rhizophagus clarus and mycorrhizal community) inserted in grafted and non-grafted tomato plants. The experiment was designed entirely at random, with five replications. The evaluations in the root system of the plants were carried out at 30 and 120 days after transplantation (DAT). Grafted plants evaluated at 30 DAT showed greater mycorrhizal colonization when cultivated with R. clarus. However, in the 120 DAT evaluation, the greatest mycorrhizal colonization was observed in non-grafted plants produced with the mycorrhizal community. At 120 DAT, the plants produced with the mycorrhizal community showed a more developed root system in relation to nonmycorrhized plants. The root system of plants non-grafted at 120 DAT was more robust when compared to grafted plants. In conclusion, the AMF-grafting interface interferes in the mycorrhizal colonization of the root system of tomato plants. The grafting technique does not improve the development of the root system. The inoculation of tomato plants with the mycorrhizal community enhances the development of roots at 120 DAT.
\end{abstract}

Keywords: arbuscular mycorrhiza, propagation, roots, Solanum lycopersicum L.

\section{Introduction}

Tomato (Solanum lycopersicum L.) is one of the main horticultural crops produced in many parts of the world (Al-Karaki, 2006). The tomato production in Brazil (4.1 million tons) is still concentrated in the conventional cultivation system (in the soil, in open sky), with low productivity $\left(65.1 \mathrm{t} \mathrm{ha}^{-1}\right)$ when compared to the countries considered the biggest producers, such as the United States of America (90.2 $\mathrm{h} \mathrm{ha}^{-1}$ ) and Spain (86.1 $\mathrm{tha}^{-1}$ ). These data show the Brazilian challenge to introduce new technologies to reduce the distance of productivity among the most developed countries and to improve the performance of the culture. As a result, in the Southern Brazil most producers are migrating from traditional cultivation on soil to substrate cultivation (container).

The substrate cultivation profile (hydroponics) is characterized by requiring many chemical fertilizers (Andrade et al., 2017). Still, one of the factors that limits the production of tomato plants is their susceptibility to phytopathogens, especially those that inhabit the growth medium and, therefore, the use of biocides is frequent during the cultivation of this horticultural crop. For these and other reasons, soilless technology needs high investment, which is sometimes not viable for tomato producers. The use of arbuscular mycorrhizal fungi (AMF) and/or the grafting technique can be a less expensive and a sustainable solution to combat the adverse effects of monoculture, instead of costly soilless culture (Vosátka et al., 2012). Thus, for tomato producers to introduce these technologies during cultivation and at the same time enhance sustainable agriculture, the following question arises: how the association between AMF and grafting technique affects the performance of the root system of tomato plants grown on substrate?

The grafting technique is commonly used in horticultural crops of fruits, including solanaceous crops 
(Ombódi et al., 2019), with the objective of improving plant tolerance to biotic (Lee, 2007) and abiotic stresses (Rouphael et al., 2017). The introduced plant (graft) has the function of improving the agronomic and qualitative characteristics of the fruits, while the host plant (rootstock) relieves biotic and abiotic stresses, improving the sustenance in the growth medium, the water/nutrient supply and disease resistance. In addition to grafting, the use of mycorrhizae in agroecosystems is receiving increasing attention. The AMF (phylum Glomeromycota) establish symbiotic associations with $80 \%$ of the terrestrial flora (Berruti et al., 2016). The symbiotic process is coordinated by molecular signals between AMF and host plants (Kamel et al., 2017). Once symbiosis is established, there is a bidirectional flow between symbionts: the fungus provides nutrients to the plant, which allocates carbohydrates to the fungus (Garcia et al., 2016). In tomato culture, AMF benefit root biomass (Ronga et al., 2019), increase the tolerance of plants inserted in stressful environments (Kumar et al., 2015) and improve fruit production (Al-Karaki, 2006).

Although the combined benefits of $A M F$ and the grafting technique are possibly stronger than the unique effect of each, most studies have focused on investigating each of these tools in isolation. Therefore, information about arbuscular mycorrhiza in grafted horticultural crops are scarce (Rouphael et al., 2015), as is the case of tomato (Öztekin et al., 2013; Kumar et al., 2015).

In the horticultural industry, producers have traditionally focused on yield (Baum et al., 2015). However, as the most important benefit of the AMF corresponds to the changes that occur in the architecture and morphology of the roots, to improve access to water and nutrients (Wu et al., 2010), no study was concerned with analyzing the root system of the plants in detail. The thinner the roots of the plant symbiont, the greater the chances of colonization by AMF (Zou et al., 2017), which can result in improvements in the acquisition of resources, as these roots, in addition to being more easily associated with AMF, are the ones that most acquire and use the resources available in the plant growth medium (McCormack et al., 2015).

Therefore, based on the hypothesis that mycorrhized and grafted tomato plants have better root growth and development, here we investigate if the association between AMF and the grafting technique modifies the performance of the root system of tomato plants grown on substrate.

\section{Materials and Methods}

The research was developed at the Universidade de Passo Fundo (28 15' 46" S, 52 24' 24" W), Rio Grande do Sul (RS), Brazil, in a greenhouse, during the period of December (summer) 2016 to April (fall) 2017.

Plant material in this study corresponded to tomato seedlings. The seedlings were produced in October (spring) 2016 at the Hortimudas nursery, in the city

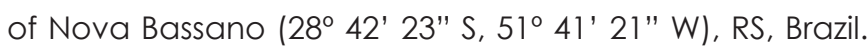
The cultivar used as a graft was 'Paron', belonging to the salad group and with an indeterminate growth habit, and the rootstock chosen was the 'Schincheonggang', an indeterminate growth hybrid. The grafting technique used was a bevel cut with a tube clip. Subsequently, the seedlings (grafted and non-grafted) were acclimatized in a greenhouse in the Hortimudas nursery, of $220 \mathrm{~m}^{2}$, with a semicircular roof, installed in the north-south direction, from October to December 2016.

The treatments used in this study were absence of inoculation (control) and two inoculants of AMF [Rhizophagus clarus (T.H. Nicolson \& N.C. Schenck) C. Walker \& A. Schüßler and a mycorrhizal community (Table 1)] inserted in non-grafted tomato seedlings ('Paron' cultivar only) and grafted ('Paron' cultivar as a graft and 'Schincheonggang' hybrid as rootstock). The experiment was designed entirely at random, with treatments arranged in a bifactorial scheme $(3 \times 2)$, with five replications ( $n=5$ ) of a single plant.

Table 1. AMF community identified from soil collected in Passo Fundo, RS, Brazil.

\begin{tabular}{|c|c|}
\hline City & Mycorrhizal community' \\
\hline $\begin{array}{l}\text { Passo } \\
\text { Fundo }\end{array}$ & $\begin{array}{c}\text { Acaulospora mellea Spain \& Schenck, } \\
\text { Acaulospora morrowiae Spain \& Schenck, } \\
\text { Cetraspora pellucida (T.H. Nicolson \& N.C. Schenck) Oehl, F.A. Souza \& Sieverd., } \\
\text { Claroideoglomus etunicatum (W.N. Becker \& Gerd.) C. Walker \& A. SchüBler, } \\
\text { Glomus sp. and } \\
\text { Septoglomus viscosum (T.H. Nicolson) C. Walker, D. Redecker, Stiller \& A. SchüBler }\end{array}$ \\
\hline
\end{tabular}

The $R$. clarus isolate came from the International Culture Collection of Glomeromycota (CICG). The AMF community (Table 1) used came from the trap culture of soil collected in an agroecosystem grown with horticultural crops [lettuce (Lactuca sativa L.), strawberry (Fragaria $\mathrm{X}$ ananassa Duch.), cucumber (Cucumis sativus L.), sweet bell pepper (Capsicum annuum L.) and tomato], in the city of Passo Fundo (28 15' 46" S, 52 24' 24" W), RS, Brazil. 
In December 2016, after eight weeks of acclimatization in the Hortimudas nursery, the tomato seedlings produced (grafted and non-grafted) were transported to the city of Passo Fundo, RS, Brazil, and transplanted in polyethylene pots $(9 \mathrm{~L})$, filled with sterilized Carolina Soil $\stackrel{1}{ }^{\otimes}$ commercial substrate $\left(120^{\circ} \mathrm{C}\right.$ for 20 minutes). At the time of implementation of the experiment, the tomato seedlings had an average stem diameter of $3.02 \mathrm{~mm}$ and three fully expanded leaves. For treatments inoculated with AMF, $10 \mathrm{~g}$ of inoculant was added in the planting pit of the seedlings at the time of transplantation (the inoculant was not mixed with the sterile substrate).

A sample of $500 \mathrm{~g}$ of Carolina Soil II ${ }^{\otimes}$ substrate was analyzed to obtain its physical (Table 2) and chemical (Table 3) attributes.

Table 2. Physical characterization of Carolina Soil II ${ }^{\circledR}$ substrate.

\begin{tabular}{lcccccc}
\hline \multirow{2}{*}{ Substrate } & $\mathrm{D}^{1}$ & $\mathrm{TP}$ & $\mathrm{AS}$ & $\mathrm{RAW}$ & $\mathrm{BW}$ & $\mathrm{RW}$ \\
\cline { 2 - 6 } & $\left(\mathrm{kg} \mathrm{m}^{-3}\right)$ & \multicolumn{5}{c}{$\left(\mathrm{m}^{3} \mathrm{~m}^{-3}\right)$} \\
\hline Carolina Soil II & 104 & 0.914 & 0.337 & 0.260 & 0.034 & 0.283 \\
\hline $\begin{array}{l}\text { ID: density; TP: total porosity; AS: aeration space; RAW: readily available water; BW: buffer water; RW: } \\
\text { remaining water. }\end{array}$
\end{tabular}

Table 3. Chemical characterization of Carolina Soil II ${ }^{\circledR}$ substrate.

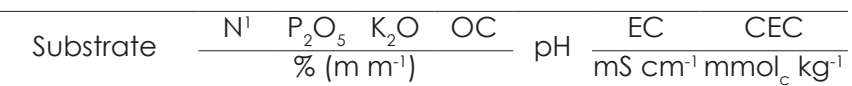

\begin{tabular}{llllllll}
\hline Carolina Soil II & 1.00 & 0.63 & 0.11 & 20.17 & 5.40 & 1.23 & 399.76
\end{tabular}

N: nitrogen: $\mathrm{P}_{2} \mathrm{O}_{5}$ : phosphorus pentoxide: $\mathrm{K}_{2} \mathrm{O}$ : potassium oxide; $\mathrm{OC}$ : organic carbon; $\mathrm{pH}$ : hydrogenionic potential; EC: electrical conductivity; CEC: cation exchange capacity.

The pots were kept in beds covered with mulching, $0.5 \times 1.0 \mathrm{~m}$ apart, in a greenhouse of $430 \mathrm{~m}^{2}$, with a semicircular roof, installed in the northwest-southeast direction. The galvanized steel frame is covered with lowdensity polyethylene film with thickness of 150 microns and antiultraviolet additive. The plants were conducted with one stem and were tutored vertically and individually with a ribbon. Drip irrigation with a flow rate of $2.4 \mathrm{~L} \mathrm{~h}^{-1}$ per pot was used in the experiment. Irrigation was applied six times a day for a total of 12 minutes per day. The nutrient solution supplied to the plants (Table 4), on a monthly basis, was adapted from Benoit (1992) to maintain the $\mathrm{K}^{+} /$ $\left(\mathrm{Ca}^{2+}+\mathrm{Mg}^{2+}\right)$ ratio needed by the tomato.

Table 4. Composition of the nutrient solution used in tomato cultivation.

\begin{tabular}{cc}
\hline Nutrient & Concentration $(\mathrm{mmol} \mathrm{L}$ \\
\hline Nitrate $\left(\mathrm{NO}_{3}\right)$ & 15.40 \\
Potassium $\left(\mathrm{K}^{+}\right)$ & 5.76 \\
Calcium $\left(\mathrm{Ca}^{2+}\right)$ & 4.50 \\
Magnesium $\left(\mathrm{Mg}^{2+}\right)$ & 1.25 \\
Sulfate $\left(\mathrm{SO}_{4}{ }^{2-}\right)$ & 1.45 \\
\hline
\end{tabular}

During the execution of the experiment, through a meteorological mini-station, we monitored the monthly averages of photosynthetically active radiation (PAR) and air temperature inside the greenhouse (Figure 1).

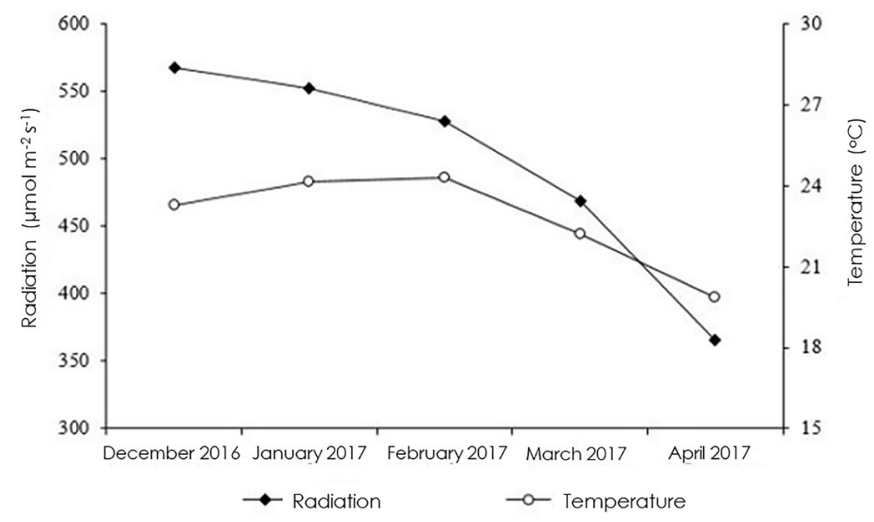

Figure 1. Monthly averages of photosynthetically active radiation and air temperature inside the greenhouse during the conduct of the experiment. The general averages of radiation and air temperature recorded during the experiment (from December 2016 to April 2017) were $496.51 \mu \mathrm{mol} \mathrm{m}^{-2} \mathrm{~s}^{-1}$ and $22.76^{\circ} \mathrm{C}$, respectively.

We performed two evaluation regarding the performance of the root system of tomato plants: 1) at 30 days after transplantation (DAT), in January (summer) 2017; 2) at 120 DAT, in April (fall) 2017. The fruit harvest started in February (summer) 2017. The average fruit production was $4.8 \mathrm{~kg} \mathrm{plant}^{-1}$ and the average lycopene content of the fruits was $8.5 \mathrm{\mu g} \mathrm{g}^{-1}$.

To verify the mycorrhizal colonization rate, at 30 DAT and 120 DAT root portions of tomato plants were prepared according to Phillips \& Hayman (1970) and their percentages of mycorrhizal colonization (MC, \%) were determined according to Trouvelot et al. (1986), by the equation:

$M C(\%)=\frac{\text { total number of fragments with mycorrhizal roots }}{\text { total number of fragments }} \times 100$

To evaluate the root system morphology at 30 DAT (January 2017) and 120 DAT (April 2017), the roots were collected and washed in water to eliminate the substrate fragments. Roots were scanned and images obtained analyzed by WinRHIZO ${ }^{\circledR}$ software. The evaluated attributes were total root length (TL, cm), surface area (SA, $\mathrm{cm}^{2}$ ) and root volume (RV, $\left.\mathrm{cm}^{3}\right)$. The roots were grouped by software in different diameter classes in relation to their total length (Böhm, 1979): very thin roots (VTR, cm: $\varnothing<0.5 \mathrm{~mm}$ ), fine roots (FR, $\mathrm{cm}$ : $\varnothing$ from 0.5 to $2.0 \mathrm{~mm}$ ) and thick roots (TR, $\mathrm{cm}: \varnothing>2.0 \mathrm{~mm}$ ).

Data were subjected to analysis of variance (Anova) and treatment means separated by the Tukey test, at $5 \%$ probability error, using the Costat ${ }^{\oplus}$ program.

\section{Results}

We observed an interactive effect of AMF and grafting on the mycorrhizal colonization of the root system of plants at 30 and 120 DAT (Table 5). Grafted plants evaluated at 30 DAT showed greater mycorrhizal colonization when they were grown with the fungal 
species R. clarus (Table 5). However, when we performed the evaluation at 120 DAT, the greatest mycorrhizal colonization was observed in non-grafted plants produced with the mycorrhizal community (Table 5).
The fungal structures formed inside the roots of tomato plants were hyphae, vesicles and arbuscules (Figure 2).

Table 5. Mycorrhizal colonization rate (\%) in roots of tomato plants with and without grafting.

\begin{tabular}{|c|c|c|c|c|}
\hline \multirow{3}{*}{ Mycorrhization } & \multicolumn{2}{|c|}{30 DAT $^{1}$} & \multicolumn{2}{|c|}{120 DAT } \\
\hline & \multicolumn{2}{|c|}{ Grafting } & \multicolumn{2}{|c|}{ Grafting } \\
\hline & With & Without & With & Without \\
\hline Control & $00.00 \pm 0.0 \mathrm{Ab}$ & $00.00 \pm 0.0 \mathrm{Ab}$ & $00.00 \pm 0.0 \mathrm{Ab}$ & $00.00 \pm 0.0 \mathrm{Ab}$ \\
\hline Community & $24.00 \pm 2.0 \mathrm{Aab}$ & $12.00 \pm 1.0 \mathrm{Ab}$ & $22.00 \pm 3.0 \mathrm{Ba}$ & $66.00 \pm 3.0 \mathrm{Aa}$ \\
\hline R. clarus & $58.00 \pm 4.0 \mathrm{Aa}$ & $36.00 \pm 3.0 \mathrm{Ba}$ & $14.00 \pm 1.0 \mathrm{Aab}$ & $22.00 \pm 2.0 \mathrm{Ab}$ \\
\hline Average & \multicolumn{2}{|c|}{22.30} & \multicolumn{2}{|c|}{20.60} \\
\hline $\mathrm{CV}(\%)^{2}$ & \multicolumn{2}{|c|}{16.70} & \multicolumn{2}{|c|}{13.80} \\
\hline
\end{tabular}
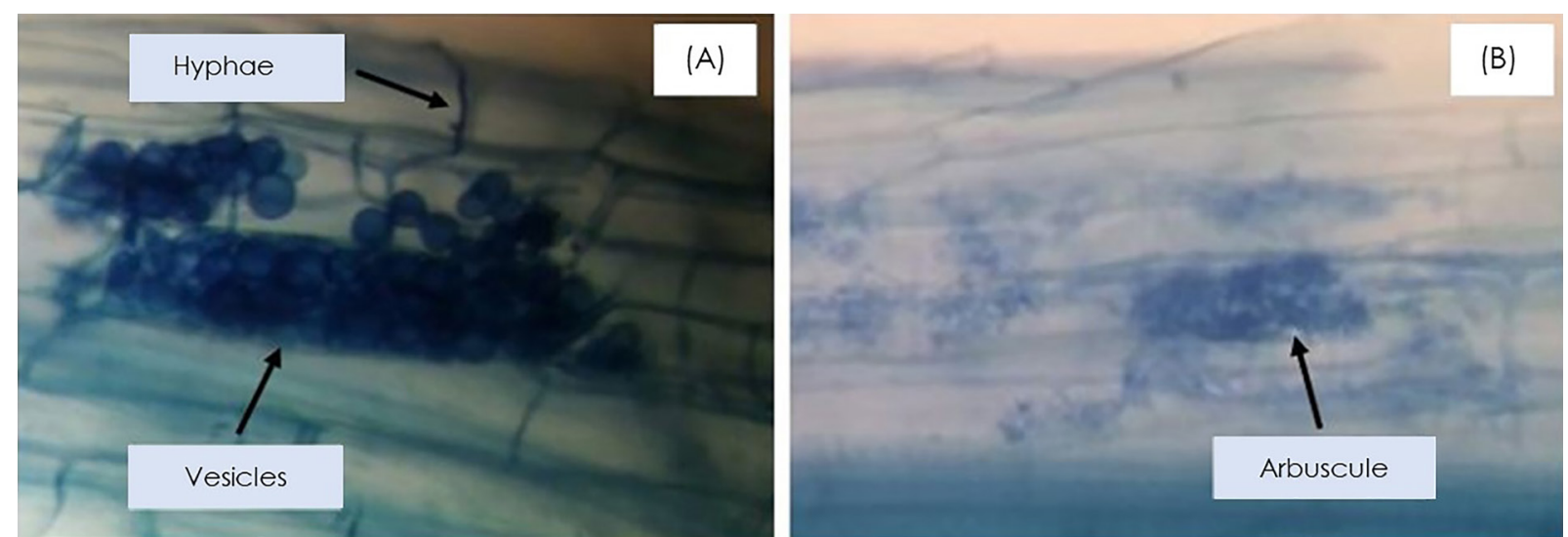

Figure 2. AMF structures visualized in roots of tomato plants referring to hyphae (A), vesicles (A) and arbuscules (B). Observation under an optical microscope, with 400x magnification.

There was an effect of AMF and grafting, independently, on the root system morphology of the plants at 30 DAT regarding the attributes SA, RV, FR and TR (Table 6). Non-mycorrhized plants showed a more robust root system, with SA, RV and TR higher in 12\%, 23\% and
$16 \%$, respectively, in relation to plants grown with AMF (Table 6). The root system of non-grafted plants proved to be more profuse, with SA, RV, FR and TR higher in 19\%, $24 \%, 22 \%$ and $30 \%$, respectively, in relation to the grafted plants (Table 6).

Table 6. Effect of mycorrhization and grafting on the root system of tomato plants 30 days after transplanting of seedlings.

\begin{tabular}{|c|c|c|c|c|}
\hline Mycorrhization & $\mathrm{SA}\left(\mathrm{cm}^{2}\right)^{1}$ & $\mathrm{RV}\left(\mathrm{cm}^{3}\right)$ & $\mathrm{FR}(\mathrm{cm})$ & $\mathrm{TR}(\mathrm{cm})$ \\
\hline Control & $812.00 \pm 53.6$ a & $26.00 \pm 2.2 \mathrm{a}$ & $634.00 \pm 43.3 \mathrm{a}$ & $231.70 \pm 10.1 \mathrm{a}$ \\
\hline Community & $759.90 \pm 51.9 \mathrm{~b}$ & $20.70 \pm 4.8 b$ & $688.90 \pm 74.3 \mathrm{a}$ & $200.50 \pm 11.7 \mathrm{~b}$ \\
\hline R. clarus & $667.30 \pm 51.1 \mathrm{~b}$ & $19.30 \pm 3.1 \mathrm{~b}$ & $535.30 \pm 46.9 \mathrm{a}$ & $187.70 \pm 10.0 \mathrm{~b}$ \\
\hline \multicolumn{5}{|l|}{ Grafting } \\
\hline With & $667.90 \pm 56.1 \mathrm{~b}$ & $19.00 \pm 1.5 \mathrm{~b}$ & $538.70 \pm 37.9 \mathrm{~b}$ & $173.40 \pm 14.2 \mathrm{~b}$ \\
\hline Without & $831.60 \pm 44.2 \mathrm{a}$ & $25.00 \pm 3.7 \mathrm{a}$ & $696.10 \pm 47.0 \mathrm{a}$ & $249.30 \pm 18.1 \mathrm{a}$ \\
\hline Average & 749.70 & 22.00 & 574.66 & 208.52 \\
\hline $\mathrm{CV}(\%)^{2}$ & 16.10 & 24.40 & 20.09 & 18.60 \\
\hline
\end{tabular}

The effect of AMF and grafting also occurred independently in the root system morphology of the plants evaluated at 120 DAT regarding the attributes $T L$, VTR, FR and TR (Figures 3 and 4).

At 120 DAT, the plants produced with the mycorrhizal community showed a more developed root system, with TL, VTR, FR and TR higher in 46\% (Figure 3A),
52\% (Figure 3B), 50\% (Figure 3C) and $54 \%$ (Figure 3D), respectively, in relation to plants grown without AMF. Plants produced with the fungal species $R$. clarus formed an intermediate group between those grown without AMF and with the mycorrhizal community (Figure 3).

When analysing tomato plants at 120 DAT for grafting, we observed that the root system of the non- 
grafted plants proved to be more robust, with FR and TR higher in 33\% (Figure 4A) and 30\% (Figure 4B), respectively, in relation to grafted plants.
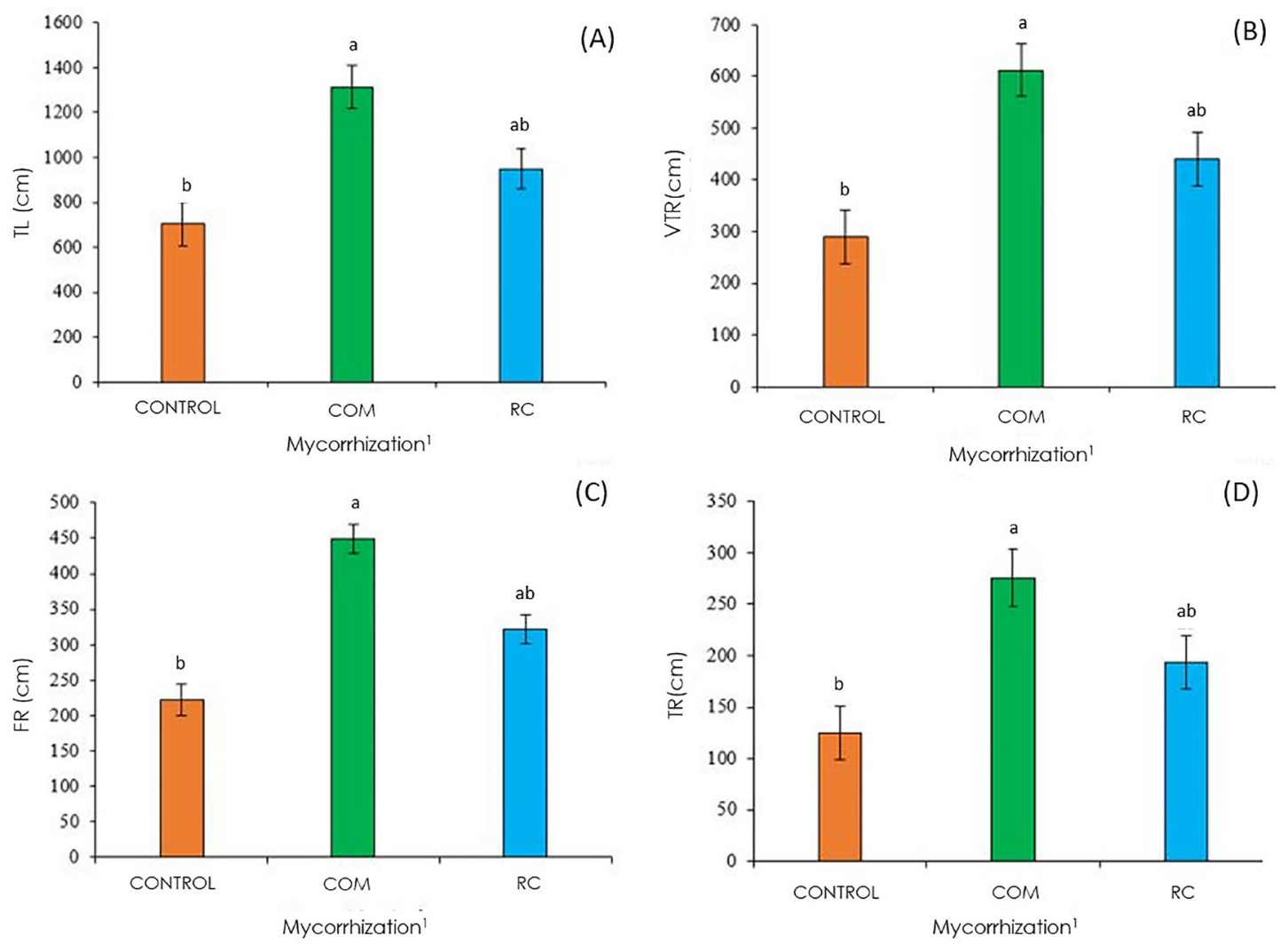

Figure 3. Root system morphology of tomato plants, in the presence and absence of mycorrhization, 120 days after transplanting of seedlings. A) Total length (TL); B) very thin roots (VTR); C) fine roots (FR); D) thick roots (TR). Data presented as mean \pm standard deviation. Different letters above columns indicate significant differences by the Tukey test ( $\mathrm{p} \leq 0.05, \mathrm{n}=5$ ). ' CONTROL: plants without mycorrhization; COM: mycorrhizal community; RC: R. clarus.
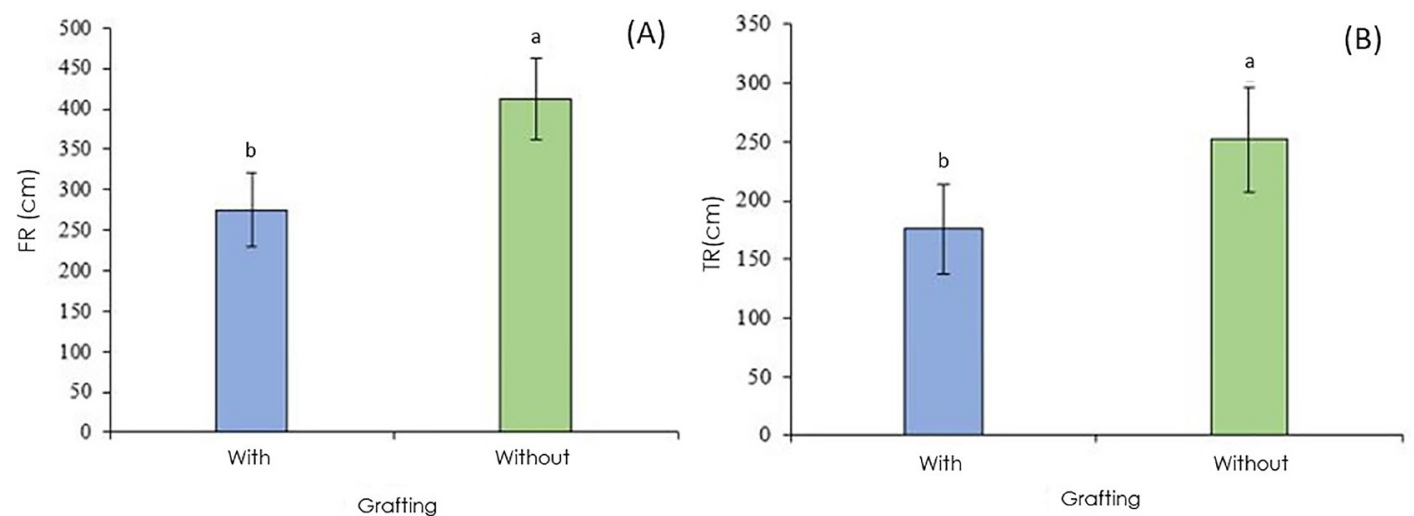

Figure 4. Root system morphology of tomato plants, in the presence and absence of grafting, 120 days after transplanting of seedlings. A) Fine roots (FR); B) thick roots (TR). Data presented as mean \pm standard deviation. Different letters above columns indicate significant differences by the Tukey test $(p \leq 0.05, n=5)$.

\section{Discussion}

Here, we show that the association between AMF and the grafting technique interfered in the mycorrhizal colonization of the root system of tomato plants grown on substrate. The grafting technique, independently, did not improve the development of the root system of tomato plants. Still, in isolation, mycorrhization promoted the main effect during tomato cultivation, potentiating the development of roots at 120 DAT when the plants were grown with the mycorrhizal community.

At 30 DAT, mycorrhizal colonization was more effective in plants grafted and cultivated with the fungal species $R$. clarus (Table 5). However, this did not reflect a better development of the root system of these plants 
(Table 6). Although mycorrhizal colonization is important, the percentage of root infectivity is not always correlated with the efficiency of symbiosis (Konvalinková \& Jansa, 2016). We believe that the fungus $R$. clarus may have taken on a role as root of the plants, which were still small and had a poorly developed aerial part. In general, plants invest in the establishment of symbiosis for the benefits that can be received in this association, such as increasing the contact area of the roots with the substrate inside the pot. This is because in the early stages of plant development (30 DAT, for example) the secondary roots are still inefficient in acquiring water and nutrients.

We mostly observed that there was a reduction in mycorrhizal colonization from 30 DAT to 120 DAT (Table 5). As younger plants have cell walls with lower calcium levels, this facilitates the association with AMF, which is important for the accumulation of reserve substances necessary for the survival of plants after transplantation. The middle lamella, a layer that interfaces between the cell walls of adjacent cells, expands until the cell reaches its maturity and possibly forms secondary walls. As this layer grows, the demand for pectic compounds also increases. To promote the connection between the pectin networks and the stability of the middle lamella, calcium in its ionic form $\left(\mathrm{Ca}^{2+}\right)$ is required. Thus, younger plants, with cells still expanding, have cell walls with lower calcium levels (Taiz et al., 2017). Ass an exception, the mycorrhizal colonization of non-grafted and cultivated plants with the AMF community increased from 30 DAT to 120 DAT (Table 5). AMF are generally nonspecific and with a very large host range. However, the greater the mycorrhizal diversity in a growth medium (soil/substrate), the greater the possibility of association with the host plant (Chiomento et al., 2019). We believe that this exception occurred due to the number of species (six, Table 1) present in the inoculum of the mycorrhizal community. Possibly some of these fungal species had greater affinity with tomato plants at this time of the evaluation (120 DAT).

Not all AMF behave the same in a given environment (Gómez-Bellot et al., 2015). Thus, host responses to mycorrhizal inoculation vary according to their phenological stage (Jiménez-Leyva et al., 2017), edaphoclimatic conditions (Halder et al., 2018) and management/agricultural practices (Velázquez et al., 2018). In addition, the relationship character of a specific microorganism and its host plant varies over time, causing a shift from mutualism to parasitism and vice versa.

Different from what we expected, the root system of plants at 30 DAT grew more when they were not mychorrhized (Table 6). This suggests that AMF initially demand carbon from the host for maintenance and then return this benefit to the plant symbiont. It is possible that many mycorrhizal associations can change from beneficial (mutualism) to harmful (parasitism) to plants (Johnson et al., 1997), inducing negative growth responses in relation to non-mycorrhized plants (Smith \& Smith, 2013), which was observed in our study (Table 6). In the case of non-mycorrhized plants, which presented a more developed radicular system (Table 6), the partition between photoassimilates occurs only between the different organs of the plants, resulting in a greater energy balance for the emission, growth and development of the roots.

On the other hand, we confirmed that the root system of plants inoculated with the mycorrhizal community at 120 DAT was more robust and profuse (Figure 3). Other researches have reported the benefit of mycorrhization to the root system of tomato plants, using biomass (Öztekin et al., 2013; Ronga et al., 2019), but without analyzing the roots in detail (using the WinRHIZO ${ }^{\circledR}$ software) as in our study [TL $(\mathrm{cm})$, SA $\left(\mathrm{cm}^{2}\right), \mathrm{RV}\left(\mathrm{cm}^{3}\right)$, VTR $(\mathrm{cm}), F R(\mathrm{~cm})$ and TR $(\mathrm{cm})]$. Due to the plasticity of the roots, their characteristics can be modulated by several factors, including the AMF (Hodge et al., 2009). During the symbiotic process, in order to occur the association between the host and the fungus, a cascade of molecular signaling is initiated, including a diffusible factor of AMF called the "Myc factor" (chitooligosaccharides), which stimulates the formation of thinner roots (Oláh et al., 2005), altering the root system morphology of the plants.

Root system changes under mycorrhization may be related to the allocation of sugars to the roots (WU et al., 2011) and hormonal regulation (Zou et al., 2017), regardless of symbiotic signaling (Gutjahr et al., 2009). Arbuscular mycorrhiza causes morphological, nutritional and physiological changes in host plants to combat stress and improve plant growth and vigor (Alqarawi et al., 2014). However, more importantly, the AMF modify the root architecture to improve access to water and nutrients (Wu et al., 2010).

As a differentiator from other studies carried out on tomato plants, which used only the genera Claroideoglomus, Glomus, Funneliformis or Rhizophagus as inoculants, our results are unprecedented because the plants were also inoculated with a mycorrhizal community from soil adapted to the cultivation of horticultural crops, including tomato (Table 1). One of the factors that influences the positive effects of arbuscular mycorrhiza is the choice of fungal species (Fortuna et al., 1992).

AMF genera, species and isolates need to be 
studied for their biotechnological potential to benefit the growth/development of the plant symbiont before being used commercially (Taylor \& Harrier, 2001). Commercial inoculants based on AMF are usually formed by only one or a few species, which may or may not be well adapted to the conditions where they are applied (Garland \& Schroeder-Moreno, 2011). Inoculation with native AMF populations, as is the case with the fungal community used in our study (Table 1), commonly provides more satisfactory results (Figure 3 and Table 5) due to fungushost compatibility and for increasing mutualistic effects with two or more symbionts instead of just one (Koron et al., 2014).

Contrary to what we hypothesized, our results showed that grafting on tomato plants did not benefit the development of the root system of plants at 30 DAT (Table 6) and 120 DAT (Figure 4). Our results contradicted researches already carried out (Öztekin et al., 2013; Kumar et al., 2015). However, we emphasize that these studies reported the benefits of grafting or the graftingmycorrhization interface in tomato plants under limiting conditions, generally subjecting plants to abiotic stresses (Öztekin et al., 2013; Kumar et al., 2015), which did not happen in our study. Positive or negative changes can occur in grafted plants. The role of AMF in vegetables submitted to the grafting technique is to improve nutrition and provide greater vegetative growth for rootstocks. The benefits derived from symbiosis depend on the particular combination of AMF and rootstock (Anzanello et al., 2011) and this did not reflect benefits on the roots of the plants evaluated in our work.

In this study, although in general the grafting technique did not have a significant influence on the development of tomato plant roots, the mycorrhizal association potentiated the root system of the plants. Our results are unprecedented when determining the influence of mycorrhizal biotechnology on tomato plants through an AMF community obtained from soil adapted to the cultivation of horticultural crops (Table 1). In addition, through the WinRHIZO ${ }^{\circledR}$ software, we were able to analyze in detail the root system of the plants. The findings of our study may be useful to tomato producers who want to insert the AMF, in the cultivation agroecosystem, as a biotechnological tool in favor of environmental sustainability. This is because tomato plants grown with AMF had higher amounts of finer roots, which are the most efficient in acquiring resources (water and nutrients, for example) from the plant growth medium (soil or substrate). Thus, the AMF would function as biofertilizers, which allows reducing the use of chemical inputs during the cultivation of this horticultural crop. Finally, these investigations are filling the gap between AMF engineering related to grafting techniques in tomato cultivation.

\section{Conclusions}

We conclude that the association between AMF and the grafting technique interferes in the mycorrhizal colonization of the root system of tomato plants grown on substrate. In younger plants (30 DAT) and grafted, the mycorrhizal colonization rate in the roots is enhanced by the fungal species R. clarus. However, in more advanced stages of development (120 DAT), plants non-grafted and produced with the AMF community have greater mycorrhizal colonization. On the other hand, we reject the hypothesis that mycorrhized and grafted tomato plants have better root growth. The grafting technique, by itself, does not improve the development of the root system of plants. In addition, in isolation, mycorrhization promotes the main effect during tomato cultivation. This symbiosis does not benefit the root system morphology of the plants at 30 DAT, but it enhances the development of roots at 120 DAT when the plants are grown with the mycorrhizal community. Although other studies have pointed out the positive effects of mycorrhizal symbiosis on the development of horticultural rootstocks, a greater understanding of the application and benefits of the AMF-grafting interface can contribute to improving the sustainability of the tomato cultivation system.

\section{Acknowledgements}

To the Programa de Suporte à Pós-Graduação de Instituições Comunitárias de Ensino Particulares (PROSUC) of the Coordenação de Aperfeiçoamento de Pessoal de Nível Superior (CAPES) and to the Universidade de Passo Fundo (UPF). We declare that the AMF used in this study are regulated by the Sistema Nacional de Gestão do Patrimônio Genético e do Conhecimento Tradicional Associado (SisGen) of the Ministry of the Environment, Brazil, according to the registration number A198F50. In addition, we inform that this study was financied in part by the Coordenação de Aperfeiçoamento de Pessoal de Nível Superior - Brazil (CAPES) - Finance Code 001.

\section{References}

Al-Karaki, G.N. 2006. Nursery inoculation of tomato with arbuscular mycorrhizal fungi and subsequent performance under irrigation with saline water. Scientia Horticulturae 109: 1-7.

Alqarawi, A.A., Abd-Allah, E.F., Hashem, A. 2014. Alleviation of salt-induced adverse impact via mycorrhizal fungi in Ephedra aphylla Forssk. Journal of Plant Interactions 9: 
802-810.

Andrade, C.A.W., Miguel, A.C.A., Spricigo, P.C., Dias, C.T.S., Jacomi, A.P. 2017. Comparison of quality between organic and conventional strawberries from multiple farms. Revista Brasileira de Fruticultura 39: e-045.

Anzanello, R., Souza, P.V.D., Casamali, B. 2011 . Fungos micorrízicos arbusculares (FMA) em porta-enxertos micropropagados de videira. Bragantia 70: 409-415.

Baum, C., El-Tohamy, W., Gruda, N. 2015. Increasing the productivity and product quality of vegetable crops using arbuscular mycorrhizal fungi: A review. Scientia Horticulturae 187: 131-141.

Benoit, F. 1992. Practical guide for simple culture techniques. European Vegetable R\&D Centre, Belgium. $72 \mathrm{p}$.

Berruti, A., Lumini, E., Balestrini, R., Bianciotto, V. 2016. Arbuscular mycorrhizal fungi as natural biofertilizers: Let's benefit from past successes. Frontiers in Microbiology 6: $1-13$.

Böhm, W. 1979. Methods of studying root systems. SpringerVerlag, Berlin, Germany. 188 p.

Chiomento, J.L.T., Stürmer, S.L., Carrenho, R., Costa, R.C., Scheffer-Basso, S.M., Antunes, L.E.C., Nienow, A.A., Calvete, E.O. 2019. Composition of arbuscular mycorrhizal fungi communities signals generalist species in soils cultivated with strawberry. Scientia Horticulturae 253: $286-294$.

Fortuna, P., Citernesi, A., Morini, S., Giovannetti, M., Loreti, F. 1992. Infectivity and effectiveness of different species of arbuscular mycorrhizal fungi in micropropagated plants of Mr S2/5 plum root stock. Agronomie 12: 825-829.

Garcia, K., Doidy, J., Zimmermann, S.D., Wipf, D., Courty, P.E. 2016. Take a trip through the plant and fungal transportome of mycorrhiza. Trends in Plant Science 21: 937-950.

Garland, B.C., Schroeder-Moreno, M.S. 2011. Influence of summer cover crops and mycorrhizal fungi on strawberry production in the Southeastern United States. HortScience 46: 985-992.

Gómez-Bellot, M.J., Nortes, P.A., Ortuño, M.F., Romero, C., Fernández-García, N., Sánchez-Blancoa, M.J. 2015. Influence of arbuscular mycorrhizal fungi and treated wastewater on water relations and leaf structure alterations of Viburnum tinus L. plants during both saline and recovery periods. Journal of Plant Physiology 188: 96105.

Gutjahr, C., Casieri, L., Paszkowski, U. 2009. Glomus intraradices induces changes in root system architecture of rice independently of common symbiosis signaling. New Phytologist 182: 829-837.

Halder, M., Dhar, P.P., Joardar, J.C., Amin, M.S., Kobir, M.H., Dey, A.K., Rahman, M.S. 2018. Effects of edaphoclimatic factors on arbuscular mycorrhiza fungi colonization in Chittagong BCSIR reserve forest, Bangladesh. Bangladesh
Journal of Botany 47: 97-104.

Hodge, A., Berta, G., Doussan, C., Merchan, F., Crespi, M. 2009. Plant root growth, architecture and function. Plant and Soil 321: 153-187.

Jiménez-Leyva, J.A., Gutiérrez, A., Orozco, J.A., Vargas, G., Esqueda, M., Gardea, A., González-Hernández, V., Sánchez, E., Muñoz, E. 2017. Phenological and ecophysiological responses of Capsicum annuum var. glabriusculum to native arbuscular mycorrhizal fungi and phosphorus availability. Environmental and Experimental Botany 138: 193-202.

Johnson, N.C., Graham, J.H., Smith, F.A. 1997. Functioning of mycorrhizal associations along the mutualism-parasitism continuum. New Phytologist 135: 575-585.

Kamel, L., Keller-Pearson, M., Roux, C., Ané, J.M. 2017. Biology and evolution of arbuscular mycorrhizal symbiosis in the light of genomics. New Phytologist 213: 531-536.

Konvalinková, T., Jansa, J. 2016. Lights off for arbuscular mycorrhiza: on its symbiotic functioning under light deprivation. Frontiers in Plant Science 7: 1-11.

Koron, D., Sonjak, S., Regvar, M. 2014. Effects of nonchemical soil fumigant treatments on root colonisation with arbuscular mycorrhizal fungi and strawberry fruit production. Crop Protection 55: 35-41.

Kumar, P., Lucini, L., Rouphael, Y., Cardarelli, C., Kalunke, R.M., Colla, G. 2015. Insight into the role of grafting and arbuscular mycorrhiza on cadmium stress tolerance in tomato. Frontiers in Plant Science 6: 477.

Lee, S.G. 2007. Production of high quality vegetable seedling grafts. Acta Horticulturae 759: 169-174.

Mccormack, M.L., Dicki, I.A., Eissenstat, D.M., Fahey, T.J., Fernandez, C.W., Dali, G., Helmisaari, H.S., Hobbie, E.A., Iversen, C.N., Jackson, R.B., Lepp€Alammi-KujansuU, J., Norby, R.J., Phillips, R.P., Kurt, S., Pregitze, K.S., Pritchard, S.G., Rewald, B., Zadworny, M. 2015. Redefining fine roots improves understanding of below-ground contributions to terrestrial biosphere processes. New Phytologist 207: 505-518.

Oláh, B., Brière, C., Bécard, G., Dénarié, J., Gough, C. 2005. Nod factors and a diffusible factor from arbuscular mycorrhizal fungi stimulate lateral root formation in Medicago truncatula via the DMI1/DMI2 signalling pathway. The Plant Journal 44: 195-207.

Ombódi, A., Gógán, A.C., Birkás, Z., Kappel, N., Morikawa, C.K., Koczka, N., Posta, K. 2019. Effects of mycorrhiza inoculation and grafting for sweet pepper (Capsicum annuum L.) crop under low-tech greenhouse conditions. Notulae Botanicae Horti Agrobotanici Cluj-Napoca 47: 1238-1245.

Öztekin, G.B., Tüzel, Y., Tüzel, H. 2013. Does mycorrhiza improve salinity tolerance in grafted plants? Scientia Horticulturae 149: 55-60.

Phillips, J.M., Hayman, D.S. 1970. Improved procedures for clearing roots and staining parasitic and vesicular- 
arbuscular mycorrhizal fungi for rapid assessment of infection. Transactions of the British Mycological Society 55: 158-161.

Redecker, D., Schubler, A., Stockinger, H., Stürmer, S.L., Morton, J.B., Walker, C. 2013. An evidence based consensus for the classification of arbuscular mycorrhizal fungi (Glomeromycota). Mycorrhiza 23: 515-531.

Ronga, D., Caradonia, F., Francia, E., Morcia, C., Rizza, F., Badeck, F.W., Ghizzoni, R., Terzi, V. 2019. Interaction of tomato genotypes and arbuscular mycorrhizal fungi under reduced irrigation. Horticulturae 5: 79.

Rouphael, Y., Franken, P., Schneider, C., Schwarz, D. Giovannetti, M., Agnolucci, M., De Pascale, S., Bonini, P., Colla, G. 2015. Arbuscular mycorrhizal fungi act as biostimulants in horticultural crops. Scientia Horticulturae 196: 91-108.

Rouphael, Y., Venema, H.J., Edelstein, M., Savvas, D., Colla, G., Ntatsi, G., Ben-Hur, M., Kumar, P., Schwarz, D. 2017. Grafting as a tool for tolerance of abiotic stress. In: Colla, G., Pérez-Alfocea, F., Schwarz, D. (eds.) Vegetable grafting: principles and practices. CAB International, Wallingford, England. p. 171-215.

Smith, F.A., Smith, S.E. 2013. How useful is the mutualismparasitism continuum of arbuscular mycorrhizal functioning? Plant and Soil 363: 7-18.

Taiz, L., Zeiger, E., Møller, I.M., Murphy, A. 2017. Fisiologia e desenvolvimento vegetal. 6.ed. Artmed, Porto Alegre, Brazil. 858 p.

Taylor, J., Harrier, L.A. 2001. A comparison of development and mineral nutrition of micropropagated Fragaria $x$ ananassa cv. Elvira (strawberry) when colonised by nine species of arbuscular mycorrhizal fungi. Applied Soil Ecology 18: 205-215.

Trouvelot, A., Kough, J.L., Gianinazzi-Pearson, V. 1986. Mesure du taux de mycorhization VA d'un systeme radiculaire: recherche de methodes d'estimation ayant une signification fonctionelle. In: Gianinazzi-Pearson, V., Gianinazzi, S. (eds.) Physiological and genetic aspects of mycorrhizae. INRA Press, Paris, France. p. 217-221.

Velázquez, M.S., Fabisik, J.C., Abarca, C.L., Allegrucci, N., Cabello, M. 2018. Colonization dynamics of arbuscular mycorrhizal fungi (AMF) in llex paraguariensis crops: Seasonality and influence of management practices. Journal of King Saud University - Science 32: 183-188.

Vosátka, M., Látr, A., Gianinazzi, S., Albrechtová, J. 2012. Development of arbuscular mycorrhizal biotechnology and industry: Current achievements and bottlenecks. Symbiosis 58: 29-37.

WU, Q.S., Li, G.H., Zou, Y.N. 2011. Improvement of root system architecture in peach (Prunus persica) seedlings by arbuscular mycorrhizal fungi, related to allocation of glucose/sucrose to root. Notulae Botanicae Horti Agrobotanici Cluj-Napoca 39: 232-236.

Wu, Q.S., Zou, Y.N., Liu, W., Ye, X.F., Zai, H.F., Zhao, L.J. 2010. Alleviation of salt stress in citrus seedlings inoculated with mycorrhiza: Changes in leaf antioxidant defense systems. Plant, Soil and Environment 56: 470-475.

Zou, Y.N., Wang, P., Liu, C.Y., Ni, Q.D., Zhang, D.J., Wu, Q.S. 2017. Mycorrhizal trifoliate orange has greater root adaptation of morphology and phytohormones in response to drought stress. Scientific Reports 7: e-41134.

Conflict of Interest Statement: The authors declare that the research was conducted in the absence of any commercial or financial relationships that could be construed as a potential conflict of interest.

All the contents of this journal, except where otherwise noted, is licensed under a Creative Commons Attribution License attribuition-type BY. 